\title{
СИСТЕМА УПРАВЛІННЯ ЯКІСТЮ НА ТУРИСТИЧНОМУ ПІДПРИЄМСТВІ: ТЕОРЕТИЧНІ АСПЕКТИ ВПРОВАДЖЕННЯ ТА ФУНКЦІОНУВАННЯ
}

\section{QUALITY MANAGEMENT SYSTEM AT A TOURIST ENTERPRISE: THEORETICAL ASPECTS OF IMPLEMENTATION AND FUNCTIONING}

\author{
Чорна Наталія Миколаївна \\ доктор історичних наук, профресор, \\ Вінницький торговельно-економічний інститут \\ Київського національного торговельно-економічного університету \\ ORCID: https://orcid.org/0000-0002-6709-6364
}

Chorna Nataliia

Vinnytsia Institute of Trade and Economics

of Kyiv National University of Trade and Economics

\begin{abstract}
У статті розкрито зміст понять «якість», «управління якістю», «система управління якістю». Проаналізовано ключові для системи управління якістю організації стандарти серії ISO. Обґрунтовано доцільність впровадження системи управління якістю на підприємстві, її розвитку та постійного поліпшування як інструменту зміцнення конкурентоспроможності, посилення ринкової влади та розширення присутності на ринку галузі. В умовах триваючої інтеграції України у європейський економічний простір, розширення каналів співпраці з зарубіжними ринками впровадження господарюючими суб'єктами системи менеджменту якості покликане зміцнити довіру до них, суттєво посприяти налагодженню та розвитку співробітництва. Доведено важливість використання систем менеджменту якості туристичними підприємствами, особливо з урахуванням катастрофрічних втрат, що їх зазнала туристична галузь від пандемії COVID-19.
\end{abstract}

Ключові слова: якість, система управління якістю, туристичне підприємство, конкурентоспроможність.

В статье раскрыто содержание понятий «качество», «управление качеством», «система управления качеством». Проанализированы ключевые для системы менеджмента качества организации стандарты серии ISO. Обоснована целесообразность внедрения системы управления качеством на предприятии, ее развития и постоянного улучшения как инструмента укрепления конкурентоспособности, усиление рыночной власти и расширение присутствия на рынке отрасли. В условиях продолжающейся интеграции Украины в европейское экономическое пространство, расширения каналов сотрудничества с зарубежными рынками внедрение хозяйствующими субъектами системы менеджмента качества призвано укрепить доверие к ним, существенно поспособствовать налаживанию и развитию сотрудничества. Доказана важность использования систем менеджмента качества туристическими предприятиями, особенно с учетом катастрофических потерь, которые понесла туристическая отрасль от пандемии COVID-19.

Ключевые слова: качество, система управления качеством, туристическое предприятие, конкурентоспособность.

The article reveals the meaning of the concepts "quality", "quality management", "quality management system", "quality management in tourism". It is stated that the quality management system is based on a systematic approach to management and allows to achieve continuous improvement of product quality, to ensure a high level of training of employees, to effectively use the resources available at the enterprise. The expediency of introduction of the quality management system at the enterprise, its development and constant improvement as a tool of strengthening of competitiveness, strengthening of the market power and expansion of presence in the market of branch is substantiated. In the context of Ukraine's ongoing integration into the European Economic Area, expanding channels of cooperation with foreign markets, the introduction of a quality management system by economic entities is designed to strengthen trust in them, significantly contribute to the establishment and development of cooperation. The key standards of the ISO series for the quality management system of the organization are analyzed. It is noted that 
the operation of the quality management system at the enterprise, certified by the certificate of compliance with international standards of the ISO 9000 series, is understood as a guarantee of its ability to stably produce quality products and, consequently, to be competitive in the market. In addition, the functioning system TQM shows that the company focuses on continuous quality improvement, minimization of production costs, delivery on time, involvement in the activities to continuously improve the quality of all staff. The key to the effective functioning of the quality management system is the identification of numerous interconnected works (processes) by the enterprise, as well as the implementation of continuous monitoring, measurement and analysis of these processes. The importance of the use of quality management systems by tourism enterprises has been proved, especially taking into account the catastrophic losses suffered by the tourism industry from the COVID-19 pandemic.

Keywords: quality, quality management system, tourist enterprise, competitiveness.

Постановка проблеми. На сучасному етапі суспільного розвитку якість є однією 3 найбільш важливих для підвищення рівня життя населення категорій, відіграє колосальну роль у забезпеченні економічної, соціальної та екологічної безпеки держави.

Діяльність будь-якого підприємства, його становище на ринку галузі визначається рівнем конкурентоспроможності, який, своєю чергою, найбільше залежить від двох показників - рівня цін та рівня якості продукції, i, що показово, саме якість у конкурентній боротьбі між товаровиробниками упродовж останнього часу набуває дедалі більшого значення. Зазначене зумовлює необхідність створення на підприємствах системи управління якістю, основною метою якої $\epsilon$ виявлення вимог споживачів, оцінка ступеня відповідності продукції, що виготовляється, цим вимогам та задоволення їх.

Система управління якістю ґрунтується на системному підході до управління та дозволяє досягти постійного вдосконалення якості продукції, забезпечувати високий рівень підготовки працівників, ефективно використовувати наявні на підприємстві матеріальнотехнічні, трудові, інфрормаційні та орінансові ресурси.

У той час, як у розвинутих зарубіжних країнах срункціонування на підприємствах систем управління якістю вже давно стало звичною справою, в Україні та більшості країн пострадянського простору створення таких систем відбувається вкрай повільно, особливо з огляду на швидкість розвитку ринку, посилення конкурентної боротьби між підприємствами різних фрорм власності, зростаючі вимоги споживачів та необхідність гарантувати якість продукції. Серед причин - відсутність методології створення систем управління якістю, десріцит компетентних кадрів, нестача знань із теорії управління якістю, обмеженість фрінансових ресурсів, а заразом недооцінка користі та практичної віддачі від впровадження цих систем на підприємствах.
Однаково актуальні для усіх галузей економіки, проблеми якості у сорері туризму стали особливо важливими у зв'язку з пандемією covid-19, яка завдала галузі катастрофічних збитків: тисячі суб'єктів туристичного бізнесу припинили свою діяльність, доходи багатьох інших скоротилися до мінімуму, а сукупні збитки за один лише 2020 рік склали 2,4 трлн дол США [1]. За таких умов якість продукції остаточно утвердилася ключовим фрактором успіху в конкурентній боротьбі, а побудова ефрективної системи управління нею перетворилася на одне 3 ключових завдань для усіх підприємств, зацікавлених не лише у зміцненні присутності на ринку, але й виході на нові ринки, встановлення відносин на довгий строк із зарубіжними партнерами.

Аналіз останніх досліджень і публікацій. Широке коло проблем управління якістю зазнало відображення у працях зарубіжних фрахівців (Е. Демінг, Г. Тагуті, Дж. Джуран, Ф. Тейлор, К. Ісікава, ін.) та їх українських колег (Н. Мережко, В. Топольник, М. Костюченко, Т. Кузьміна, М. Панченко, ін.). Багато економічних проблем розвитку туризму висвітлено в роботах Т. Ткаченко, М. Мальської, О. Любіцевої, І. Писаревського, В. Кифяка, Г. Михайліченко, М. Рутинського, Г. Горіної, ін.

Виділення невирішених раніше частин загальної проблеми. Попри це, низка аспектів проблеми управління якістю в туризмі не отримали належного відображення в науковій літературі. Недостатньо вивченими є питання створення та фрункціонування на туристичних підприємствах системи управління якістю, не обґрунтованими є вигоди суб'єктів туристичного бізнесу від ії упровадження, потребує опрацювання вимірювання ефективності системи управління якістю на туристичних підприємствах, досі не визначеними залишаються критерії і показники якості туристичного продукту, методики її визначення та оцінки, ін.

Формулювання цілей статті. Метою даної публікації $€$ обґрунтування теоретичних засад впровадження на підприємствах туристичної 
галузі системи управління якістю та забезпечення її ефективного фрункціонування.

Виклад основного матеріалу дослідження. Яксвідчить багаторічний досвід провідних компаній розвинених країн світу, здобути успіх на ринку можна лише шляхом гарантування якості. Та, якщо раніше, говорячи про якість, мали на увазі ґатунок продукції, наразі йдеться більше про якість фрункціонування підприємств, досконалість впроваджених на них систем управління якістю, націлених на постійне самовдосконалення та задоволення існуючого на ринку попиту.

Функціонування на підприємстві системи менеджменту якості, засвідченої сертифрікатом відповідності міжнародним стандартам серії ISO 9000, розуміється запорукою його здатності стабільно виробляти якісну продукцію, а відтак, бути конкурентоспроможним на ринку, в т. ч. міжнародному.

Згідно з Міжнародною організацією зі стандартизації (ISO), якість - це сукупність властивостей і характеристик продукту, які надають йому здатність задовольняти обумовлені або передбачувані потреби споживачів.

У туризмі виділяють чотири типи якості:

- якість як властивість та особливість продукту (послуги), яка викликає почуття задоволення у споживача, або відсутність недоліків, що підсилює стан задоволеності у нього;

- якість як технічна та фрункціональна характеристика продукту (послуги). Технічна якість - це все те, що отримує і споживає клі$\epsilon \mathrm{HT}$, а також те, з чим він залишається після взаємодії зі спеціалістом туристичного підприємства. Функціональне якість - це процес надання продукту (послуги), під час якого споживач проходять безліч етапів у своїй взаємодії з фрахівцями туристичного підприємства;

- якість як складова культури обслуговування, яка фрормується поведінкою працівників туристичного підприємства по відношенню до споживачів, а критеріями ії оцінки є дружелюбність, чуйність і люб'язність персоналу;

- якість як етична компонента продукту (послуги), яка може бути оцінена споживачем лише в процесі його споживання.

Таким чином, під поняття «якість» у туристичній індустрії часто розуміють правильно визначені потреби клієнтів, відповідно туристичне підприємство має створювати продукти (послуги), які відповідають потребам клієнтів. Якщо конкуренти досі не запропонували нічого подібного, у туристичного підприємства $\epsilon$ можливість досягти переваги, ставши першим на ринку. Своєю чергою, система управ- ління якістю - це сукупність взаємопов'язаних та/або взаємодіючих елементів організації, які дають змогу спрямовувати та контролювати ії діяльність щодо якості. В умовах зростаючої конкурентної боротьби саме система управління якістю підприємства може стати інструментом зміцнення конкурентних переваг та розширення присутності на ринку [2].

Найбільш есрективно запитам ринку і потребам споживачів відповідає ідеологія Загального управління якістю (Total Quality Management) - комплексної системи, що орієнтується на безперервне поліпшування якості, мінімізацію виробничих витрат, постачання точно у визначений строк, залучення до діяльності підприємства 3 постійного поліпшування якості всього персоналу. Увібравши в себе все найбільш прогресивне, що було характерним для попередніх концепцій управління якістю, модель TQM заклала фрундамент для систем управління якістю в організації, на принципи якої опираються сучасні міжнародні стандарти ISO.

Стандарти ISO є мінімальним набором правил, якими має керуватися кожна організація, діяльність якої спрямовуються на постійне покращення та зменшення кількості проблем як всередині, так і при взаємодії з зовнішнім середовищем. 3-поміж понад 20 тис. міжнародних стандартів, базовими для всіх систем управління якістю $€$ стандарти ISO серії 9000 , розроблені технічним комітетом міжнародної організації ISO (ISO/TC 176) на основі узагальнення накопиченого національного досвіду різних країн щодо розроблення, впровадження та фрункціонування систем якості.

Наразі фрундаментальними стандартами в системі стандартів ISO серії $9000 €$ :

- ISO 9000:2015 - Системи управління якістю. Основні положення та словник термінів. Стандарт встановлює основні принципи та визначає термінологію, необхідну для правильного застосування в практиці впроваджених систем управління якістю.

- ISO 9001:2015 - Системи управління якістю. Вимоги. Стандарт визначає вимоги, які організація буде виконувати, щоб задовільними потреби та очікування споживачів щодо якості.

- ISO 9004:2018 - Управління якістю. Якість організації. Настанови щодо досягнення сталого успіху. Стандарт містить настанови щодо управління організацією в складному і мінливому середовищі з позиції якості. Стандарт спрямовується на: поліпшення показників діяльності організації; задоволення 
споживачів та інших зацікавлених сторін; залучення до цих процесів всіх працівників.

- ISO 19011:2018 - Настанови щодо проведення аудитів систем управління. Стандарт містить рекомендації для організацій усіх розмірів і типів та щодо аудитів різних сорер застосування та масштабів.

Нові версії стандартів ISO 9000:2015 та ISO 9001:2015 були прийняті Міжнародною організацією зі стандартизації ISO у вересні 2015 р., ставши, таким чином, п'ятою редакцією серії стандартів ISO.

Стандарт ISO 9001:2015, на відповідність якому системи управління якістю проходять сертифікацію, від попередньої версії стандарту суттєво відрізняється очевидним застосуванням ризик-орієнтованого мисленням, яке дає змогу організації визначати чинники, які можуть спричиняти відхилення її процесів та її системи управління якістю від запланованих результатів, щоб встановлювати запобіжні заходи контролю для мінімізації негативних впливів і максимального використання можливостей, по мірі їх виникнення. Це неможливо без розуміння свого середовища і визначення зацікавлених сторін та їхніх вимог.

Вимоги стандарту ISO 9001 носять загальний характер і не передбачають забезпечення однаковості структури систем управління якістю або однаковість документації, тому що застосовні до діяльності будь-якої організації незалежно від типу, розміру та продукції, що випускається (послуги, що надається). Стандарт ISO 9001 не містить вимог до інших систем менеджменту (екологічний менеджмент, техніка безпеки й охорона праці, фрінансовий менеджмент), але дозволяє організації інтегрувати свою систему менеджменту якості з відповідними вимогами загальної системи менеджменту.

Розвиток вимог ISO 9001 засвідчило прийняття стандарту ISO 9004, не призначеного, щоправда, для цілей сертифрікації. Вимоги ISO 9004 рекомендуються як керівництво для організацій, які бажають перевищити вимоги ISO 9001 з метою вдосконалення та досягнення сталого розвитку: концепція ISO 9001 спрямована на досягнення поставлених цілей, а виконання положень ISO 9004 дозволяє досягати поставлені цілі з більшою ефективністю.

Стандарт ISO 19011 призначається для застосування широким колом потенційних користувачів, включаючи аудиторів, організації, які впроваджують системи менеджменту якості, та організації, яким необхідно проводити аудити систем менеджменту відповідно до законодавства. Проведення аудиту відпо- відно до стандарту засноване на менеджменті ризиків і передбачає застосування вибіркових досліджень на основі теорії ймовірностей і математичній статистиці.

Особливістю зазначених стандартів $є$ добровільність, адже підприємство саме приймає рішення про побудову системи менеджменту якості відповідно до стандартів серії ISO 9000, разом $з$ тим, прийнявши таке рішення, виконання вимог останніх стає обов'язковим.

Менеджмент якості в туризмі - це діяльність у рамках загальної фрункції управління туристичним підприємством, яка визначає політику у сорері якості, цілі і обов'язки в рамках системи управління якістю, здійснює їх за допомогою планування якості, забезпечення якості, управління якістю та постійне ії поліпшування.

Планування якості послуг в туризмі пов'язано зі створенням системи управління якістю як організаційної структури, що включає фрункції, документацію, процеси і ресурси, необхідні для створення, підтримки необхідного рівня якості та його поліпшення на всіх стадіях життєвого циклу продукту.

Відповідно до вимог ISO 9001, для створення системи управління якістю організація повинна:

- визначити процеси, потрібні для системи управління якістю, та їх застосування в межах організації;

- визначити необхідні входи цих процесів і очікувані від них виходи;

- визначити послідовність і взаємодію цих процесів;

- визначити та застосовувати критерії та методи (зокрема моніторингу вимірювання та відповідні показники дієвості), потрібні для забезпечування результативності фрункціювання та контролювання цих процесів;

- визначити ресурси, потрібні для цих процесів, і забезпечувати їх наявність;

- призначити осіб з відповідальністю та повноваженнями щодо цих процесів;

- розглядати ризики та можливості;

- оцінювати ці процеси та запроваджувати будь-які зміни, потрібні для забезпечування того, щоб ці процеси досягали своїх передбачених результатів;

- поліпшувати процеси та систему управління якістю.

Забезпечення якості в туризмі - це сукупність всіх запланованих та методично здійснюваних видів туристичної діяльності в рамках системи управління якістю, необхідних для створення туристичного продукту (послуги), що відповідає визначеним вимогам. 
Управління якістю туристичного підприємства на стратегічному рівні передбачає:

- розробку місії і політики у сорері якості;

- фрормування довгострокових цілей, що визначають стратегію розвитку;

- визначення вимог до системи управління якістю та умов есрективного ії фрункціонування;

- здійснення стратегічного контролю та аналізу результатів.

Управління якістю туристичного підприємства на тактичному та оперативному рівнях передбачає управління:

- забезпеченістю ресурсами;

- проектуванням і розробкою нового продукту (послуги);

- діяльністю співробітників;

- обслуговування споживачів;

- веденням документації.

Поліпшення якості послуг туристичного підприємства передбачає:

- впровадження та сертифрікацію системи менеджменту якості, відповідно до вимог стандартів серії ISO;

- надання туристичного послуг, рівень якості яких дозволяє провести їх добровільну сертифрікацію;

- самооцінку діяльності на основі критеріїв різноманітних конкурсів з якості та перемога в них.

Запорукою есрективного срункціонування системи управління якістю $є$ визначення підприємством численних взаємопов'язаних робіт (процесів) та керівництво ними, а також здійснення постійного моніторингу, вимірювання і аналізу цих процесів.

Для кількісного вимірювання ефективності системи управління якістю необхідно застосувати метод експертних оцінок, який дозволяє градацію показників визначати в балах. За такої умови зведення показників до узагальненої оцінки є можливим за допомогою ком- плексного показника - коефріцієнта ефективності системи управління якістю, розрахунок якого здійснюють за фрормулою:

$$
\mathrm{Pe}=(\mathrm{Pi} \cdot \mathrm{Wi})
$$

де $\mathrm{Pe}$ - рівень ефрективності системи управління якістю;

$\mathrm{Pi}$ - експертна оцінка і-го показника системи управління якістю;

Wi - коефріцієнт вагомості і-го показника ефективності системи управління якістю.

Такий підхід до структурування показників системи управління якістю дозволяє не лише оцінювати, але й удосконалювати їх, що сприяє підвищенню конкурентоспроможності підприємства [3].

У цілому, впровадження системи управління якістю на підприємстві призводить не тільки до покращення продукції (товарів, послуг), а й сприяє оптимізації бізнес-процесів у цілому, веде до підвищення продуктивності праці, зменшення ресурсозалежності, та як наслідок, до зниження собівартості продукції, що безпосередньо впливає на конкурентоспроможність підприємства, його позиції на ринку [4].

Висновки. В умовах зростаючої конкурентної боротьби на національному та глобальному ринках впровадження на підприємстві системи менеджменту якістю як складової загальної системи управління $\epsilon$ цілком виправданим. Функціонування на підприємстві TQM сприймається споживачами та іншими суб'єктами, з якими воно контактує, запорукою відповідальності та надійності, відтак, сприяє зміцненню конкурентних переваг та посиленню ринкової влади. Беручи до уваги деклароване Україною прагнення інтеграції до Європейського Союзу, підприємства країн якого відомі високими стандартами управління якістю, слідування останнім українськими компаніями фрактично позбавлене альтернативи.

\section{СПИСОК ВИКОРИСТАНИХ ДЖЕРЕЛ:}

1. Пандемия и туризм: глобальная экономика может лишиться более 4 трлн долларов. URL: https://news.un.org/ ru/story/2021/06/1405562

2. Глєбова А.О., Карчевський Б.О. Системи управління якістю на підприємстві в умовах євроінтеграційних процесів. Глобальні та національні проблеми економіки. 2015. Вип. 8. С. 352-356. URL: http://global-national.in.ua/ archive/8-2015/73.pdf

3. Лузан І.В., Луценко І.С. Система управління якістю як фрактор підвищення конкурентоспроможності підприємства. Актуальні проблеми економіки та управління. 2012. Вип. 6. URL: http://probl-economy.kpi.ua/ $\mathrm{pdf} / 2012-7 . \mathrm{pdf}$

4. Папп В.В., Бошота Н.В. Організаційний механізм управління якістю послуг на туристичних підприємствах. Економіка і суспільство. 2018. № 15. С. 437-443. URL: https://economyandsociety.in.ua/journals/ 15_ukr/67.pdf 


\section{REFERENCES:}

1. Pandemiya i turizm: global'naya ekonomika mozhet lishit'sya bolee 4 trln dollarov [Pandemic and tourism: the global economy could lose more than \$ 4 trillion]. Available at: https://news.un.org/ru/story/2021/06/1405562 (in Russian)

2. Glyebova A.O., Karchevskyj B.O. (2015) Systemy upravlinnya yakistyu na pidpryyemstvi v umovax yevrointegracijnyx procesiv [Quality management systems at the enterprise in the conditions of European integration processes]. Globalni ta nacionalni problemy ekonomiky, no. 8, pp. 352-356. Available at: http://global-national.in.ual archive/8-2015/73.pdf (in Ukrainian)

3. Luzan I.V., Lucenko I.S. (2012) Systema upravlinnya yakistyu yak faktor pidvyshhennya konkurentospromozhnosti pidpry yemstva [Organizational mechanism of quality management of services at tourist enterprises]. Aktualni problemy ekonomiky ta upravlinnya, no. 6. Available at: http://probl-economy.kpi.ua/pdf/2012-7.pdf (in Ukrainian)

4. Papp V.V., Boshota N.V. (2018) Orhanizatsiinyi mekhanizm upravlinnia yakistiu posluh na turystychnykh pidpryiemstvakh [Organizational mechanism for managing the quality of services in tourism enterprises]. Ekonomika $i$ suspilstvo, no. 15, pp. 437-443. Available at: https://economyandsociety.in.ua/journals/15_ukr/67.pdf (in Ukrainian) 